\title{
Pharmaceutical and nutraceutics on three endemic species of Ceropegia Sp.
}

Binish T.* and Pushpa R.

Department of Botany, Adhiyaman Arts and Science College for Women, Uthangarai, Krishnagiri Dt, Tamilnadu, India.

Received: 4/9/2018; Revised: 4/18/2018; Accepted: 4/27/2018

\begin{abstract}
Plants are the richest resource of drugs of traditional systems of medicine and modern medicines. Medicinal plant species has its own nutrient composition besides pharmacologically important phytochemicals. Nutraceutics is an emerging field of therapy. As we come to the end of this millennium, more and more people are getting health conscious and are looking at dietary substances for preventive or curative effects. The importance of minerals such as potassium, calcium, sodium etc. to human health is well known. The nutritional values and mineral composition of medicinal plants are being used as dietary supplements by humans. The nutritional compositions of selected Ceropegia species were found as good nutritive value. Nutritive compositions were analyzed and compared in vitro plant parts of Ceropegia spiralis, Ceropegia candelabrum and Ceropegia juncea. Sixty to seventy five days old in vitro plants were taken for biochemical studies of total proteins, total carbohydrates, sugar, starch and amino acid.Among the three samples analyzed, high protein sugar and aminoacids content was noticed in Ceropegia juncea and total carbohydrates and protein values high in Ceropegia candelabrum, Ceropegia candelabrum was found to be a rich source of iron (18.55 \pm 0.11$)$ followed by Ceropegia juncea (17.74 \pm 0.25$)$ and Ceropegia spiralis (17.56 \pm 0.25$)$. Nutraceuticals importance of these valuable plants may help in future for the production of new medicines and valuable food stuffs. The secondary metabolites present in them has a specific medicinal benefit other than a purely nutritional. These species are utilized for Indian system of medicine and scientists encourage them to rationalize it suiting the modern requirements of biotechnology.
\end{abstract}

Key words: Nutraceutics; In vitro; Ceropegia; Species

\section{Introduction}

In modern medicine, plants continue to provide with us new chemical entities. Secondary metabolites are used as pharmaceutical, agrochemicals, aromatics and food additives. Pharmacologists, microbiologists, biochemists, botanists and natural-product chemists all over the world are currently investigating medicinal herbs for phytochemical and lead compounds that could be developed for treatment of various diseases (Acharya et al., 2011). In recent years, secondary plant metabolites (Phytochemicals), previously with unknown pharmacological activities, have been extensively investigated as a source of medicinal agents (Erdo- grul, 2002; Krishnaraju et al., 2005; Mahesh and Satish, 2008). The phytochemical investigation of raw drugs revealed a narrow spectrum of constituents in larger quantities traded in the market as the raw constituents (Uniyal et al., 2006). Medicinal plant species has its own nutrient composition besides pharmacologically important phytochemicals. These nutrients are essential for the physiological functions of human body. Such nutrients and biochemical like carbohydrates, fats and proteins play an important role in satisfying human needs for energy and life processes.

\footnotetext{
*Corresponding Author:

Binish T.,

Assistant Professor, Department of Botany,

Adhiyaman Arts and Science College for Women,

Uthangarai, Krishnagiri Dt, Tamilnadu, India.

E-mail: binisht2013@gmail.com
}

The nutritive and medicinal values of the Ceropegia (Apocynaceae) species has been extensively used for the preparation nutritive tonic in Ayurvedic system. These Ceropegia species are placed under the categories of rare, endangered, vulnerable, extinct and threatened plants (Nayar and Sastry, 1987; Goyal and Bhadauria, 2006). Twenty-eight species of Ceropegia are endemic to the Peninsular India (Ansari, 1984; Ahmedulla and Nayar, 1986). Tissue culture techniques are the effective tools to conserve plants from extinction, homogenous production, maintain stable plant source produced them in large quantities and restore them to the natural habitats (Murch et al., 2000a; Cambell et al., 2003; Dave et al., 2003; Bapat et al., 2008; Sidhu, 2010). Ceropegia species are generally used for the preparation of medicine for the treatment of stomach and gastric disorders. Moreover, the tuberous roots of Ceropegia spiralis and Ceropegia candelabrum have great nutritive value. They are widely eaten by folks and other rural people.

\section{Materials and Methods}

Nutritional analysis

Sixty to seventy-five days old in vitro plants Ceropegia juncea, Ceropegia spiralis and Ceropegia candelabrum were taken for biochemical studies. 

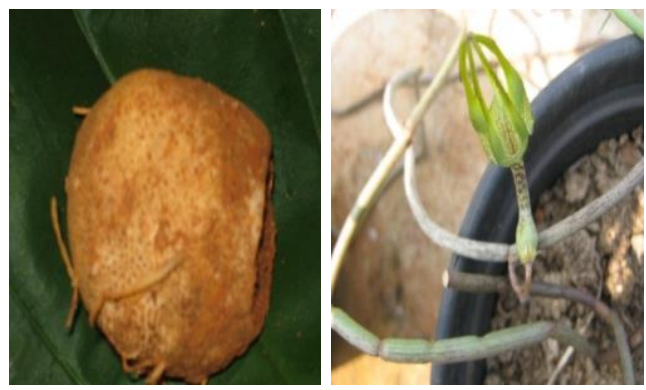

C. spiralis

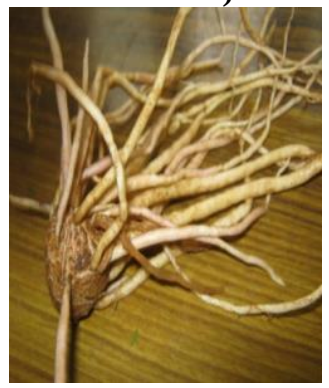

C. candelabrum tuberous root

Determination of total carbohydrate by anthrone method

Weigh $100 \mathrm{mg}$ of the sample into a boiling tube. Hydrolyze by keeping it in a boiling water bath for three hours with $5 \mathrm{ml}$ of $2.5 \mathrm{~N} \mathrm{HCl}$ and cool to room temperature. Neutralize it with solid sodium carbonate until the effervescence ceases. Make up the volume to $100 \mathrm{~mL}$ and centrifuge. Collect the supernatant and take 0.5 and $1 \mathrm{~mL}$ aliquots for analysis. Prepare the standards by taking $0,0.2,0.4$, $0.6,0.8$ and $1 \mathrm{~mL}$ of the working standard. ' 0 ' serves as blank. Make up the volume to $1 \mathrm{~mL}$ in all the tubes including the sample tubes by adding distilled water. Then add $4 \mathrm{~mL}$ of anthrone reagent, heat for eight minutes in a boiling water bath. Cool rapidly and read the green to dark green color at $630 \mathrm{~nm}$. Draw a standard graph by plotting concentration of the standard on the $\mathrm{X}$-axis versus absorbance on the Y-axis. From the graph calculate the amount of carbohydrate present in the sample tube.

\section{Calculation}

$100 \mathrm{mg}$ of the sample $=\frac{\mathrm{mg} \text { of the glucose }}{\text { volume of test sample }} \times 100$

\section{Estimation of starch by Anthrone reagent}

Homogenize 0.1-0.5 g of the sample in hot $80 \%$ ethanol to remove sugars. Centrifuge and retain the residue. Wash the residue repeatedly with hot $80 \%$ ethanol till the washings do not give color with anthrone reagent. Dry the residue well over a water bath. To the residue add $5.0 \mathrm{~mL}$ of water and 6.5 $\mathrm{mL}$ of $52 \%$ perchloric acid. Extract at $0^{\circ} \mathrm{C}$ for 20 min. Centrifuge and save the supernatant. Repeat the extraction using fresh perchloric acid. Centrifuge and pool the supernatants and make up to $100 \mathrm{~mL}$. Pipette out 0.1 or $0.2 \mathrm{~mL}$ of the supernatant and make up the volume to $1 \mathrm{~mL}$ with water. Prepare the standards by taking 0.2, 0.4, 0.6,
0.8 and $1 \mathrm{~mL}$ of the working standard and make up the volume to $1 \mathrm{~mL}$ in each tube with water. Add 4 $\mathrm{mL}$ of anthrone reagent to each tube, heat for eight minutes in a boiling water bath. Cool rapidly and read the intensity of green to dark green color at $630 \mathrm{~nm}$.

\section{Calculation}

Find out the glucose content in the sample using the standard graph. Multiply the value by a factor 0.9 to determin the starch content.

\section{Estimation of sugar by anthrone method}

Known amount of $(100 \mathrm{mg})$ in vitro plant sample cut into small bits and boiled in $20 \mathrm{ml}$ of distilled water in a boiling water-bath for 20 minutes and were needed for complete extraction of sugar in water. It was cooled and made up to known volume again with distilled water. $0.1 \mathrm{ml}$ of the extract was taken and made up to $1 \mathrm{ml}$ with distilled water, $4 \mathrm{ml}$ of anthrone reagent was added and incubated in a boiling water-bath for $15 \mathrm{~min}$. It was cooled and measured the absorbance of the blue color in a UVSpectrophotometer at $620 \mathrm{~nm}$. The amount of total sugar present in the sample was calculated using the standard graph.

\section{Extraction of protein from sample}

Extraction is usually carried out with buffers used for the enzyme assay. Weigh $100 \mathrm{mg}$ of the sample and grind well with a pestle and mortar in $5-10 \mathrm{ml}$ of the buffer. Centrifuge and use the supernatant for protein estimation.

\section{Estimation of protein}

Pipette out $0.1 \mathrm{ml}$ of the sample extract in test tubes. Make up the volume of $1 \mathrm{ml}$ in all the test tubes. A tube with $1 \mathrm{ml}$ of water serves as a blank. Add $5 \mathrm{ml}$ of reagent $(2 \%$ Sodium carbonate in $0.1 \mathrm{~N}$ sodium hydroxide (Reagent A), 0.5\% Copper sulphate $\left(\mathrm{CusO}_{4} .5 \mathrm{H}_{2} \mathrm{O}\right)$ in $1 \%$ Potassium sodium tartrate (Reagent B), Alkaline copper solution (Reagent C); Mix $50 \mathrm{ml}$ of $\mathrm{A}$ and $1 \mathrm{ml}$ of $\mathrm{B}$ prior to the use Reagent $C$ to each tube including the blank. Mix well and allow standing for $10 \mathrm{~min}$. Then add $0.5 \mathrm{ml}$ of reagent D (Folin-Ciocalteau reagent), mix well and incubate at room temperate in the dark for $30 \mathrm{~min}$. Blue color develops. Take the readings at $660 \mathrm{~nm}$ in UV-Spectrophotometer. The absorbance was plotted against standard graph prepared with $\mathrm{BSA}$ and the amount of proteins were calculated and presented in the form of tables.

\section{Amino acid quantification}

Weigh $1 \mathrm{gm}$ of the in vitro plant sample and ground it in a mortar and pestle with $10 \mathrm{ml}$ of $80 \%$ ethanol. Filter through a fine cloth and centrifuged the filtrate at $500 \mathrm{rpm}$ for 5 minutes. Discard the pellet and adjust the total volume of supernatant at $10 \mathrm{ml}$ with $80 \%$ ethanol. This is the extract. Take $2 \mathrm{ml}$ of the extract and add $2 \mathrm{ml}$ of $0.1 \%$ ninhydrin reagent. Shake well and heat it in a boiling waterbath for 15 
minutes until bluish purple color appears. Colour to room temperature and add $3 \mathrm{ml}$ of $50 \%$ ethanol. Prepare blank simultaneously. Optical density was read at $510 \mathrm{~nm}$. Extra polate the OD value and calculate the amount of amino acid present in the given plant tissue using standard graph.

\section{Determination of ash content}

5 gram of each powdered dried plant material (in vitro propagated plant material) was taken in the previously weighed porcelain crucible. The crucible was heated first over a low flame till all the material was completely charred, followed by heating in a Bunsen furnace for about 3 to 5 hours at $600^{\circ} \mathrm{C}$. It was cooled in desiccators and weighed to ensure completion of ash formation. Further, it was heated again in the furnace for 30 minutes. Cooled and weighed. Repeat till the weight becomes constant.

\section{Preparation of plant samples for mineral analysis}

One gram of ash was taken in Kjeldhal flask, $20 \mathrm{ml}$ of dilute HCL was added and digestion was carried out on a low flame initially for 10 to 15 min until frothing stops. The digestion at high temperature was carried out for 1 hour or till the contents of Kjeldhal flask become clear. Cooled the flask and transfer the content to $100 \mathrm{ml}$ volumetric flask and adjusted the final volume to $100 \mathrm{ml}$ by adding distilled water. Use the solution for determination of mineral elements through the atomic absorption spectroscopy (AAS) and the flame photometry (FPM). Prepared the standard solution of each element drawn the calibration curves for each element using AAS/FPM.

\section{Results}

Table 1. Nutritional values of Ceropegia juncea, Ceropegia spiralis and Ceropegia candelabrum (100mg)

\begin{tabular}{lccccc}
\hline Plant name & $\begin{array}{c}\text { Total } \\
(\mathbf{M e a n} \pm \mathbf{S D})\end{array}$ & $\begin{array}{c}\text { proteins } \\
\text { (Mean } \pm \text { SD) }\end{array}$ & $\begin{array}{c}\text { Sotal carbohydrates } \\
\text { (Mean } \pm \text { SD) }\end{array}$ & $\begin{array}{c}\text { Starch } \\
(\mathbf{M e a n} \pm \mathbf{S D})\end{array}$ & $\begin{array}{c}\text { Aminoacid } \\
(\mathbf{M e a n} \pm \mathbf{S D})\end{array}$ \\
\hline Ceropegia juncea & $713.3 \pm 70.2$ & $421.6 \pm 18.7$ & $338.3 \pm 14.6$ & $14.3 \pm 1.5$ & $55.3 \pm 4.7$ \\
Ceropegia spiralis & $681.6 \pm 12.5$ & $344.3 \pm 4.0$ & $288.7 \pm 10.1$ & $14.0 \pm 1.4$ & $44.4 \pm 3.1$ \\
Ceropegia candelabrum & $383.6 \pm 3.2$ & $461.6 \pm 2.8$ & $272.6 \pm 6.8$ & $15.3 \pm 2.0$ & $31.4 \pm 0.9$ \\
\hline
\end{tabular}

Each value represents mean value \pm SD of experiment carried out with three replicates.

On analysis of nutritional compositions, it was found that selected sampling plants contained varied protein contents. Protein content of Ceropegia juncea showed good protein content of $713.3 \pm 70.2$ $\mathrm{mg} / \mathrm{g}$ followed by Ceropegia spiralis $681.6 \pm 12.5$ $\mathrm{mg} / \mathrm{g}$ and Ceropegia candelabrum $383.6 \pm 3.2 \mathrm{mg} / \mathrm{g}$. On analysis of the results obtained, it was found that Ceropegia candelabrum contained the highest quantity of carbohydrates (mean $\pm \mathrm{SD}=461.6 \pm$ $2.8 \mathrm{mg} / \mathrm{g}$ ) followed by Ceropegia juncea (mean $\pm \mathrm{SD}$ $=421.6 \pm 18.7 \mathrm{mg} / \mathrm{g}$ ) and Ceropegia spiralis (mean \pm $\mathrm{SD}=344.3 \pm 4.0 \mathrm{mg} / \mathrm{g})$.
In Ceropegia juncea the amount of sugar was $338.3 \pm$ $14.6 \mathrm{mg} / \mathrm{g}$ followed by Ceropegia spiralis $288.7 \pm$ $10.1 \mathrm{mg} / \mathrm{g}$ and Ceropegia candelabrum $272.6 \pm$ $6.8 \mathrm{mg} / \mathrm{g}$. Among the three samples analyzed, high starch content was noticed in Ceropegia candelabrum with mean $\pm \mathrm{SD}$ value at $15.3 \pm 2.0 \mathrm{mg} / \mathrm{g}$, followed by Ceropegia juncea $14.3 \pm 1.5 \mathrm{mg} / \mathrm{g}$ and Ceropegia spiralis $14.0 \pm 1.4 \mathrm{mg} / \mathrm{g}$. On analysis, Ceropegia juncea showed high amino acid content of $55.3 \pm 4.7$ $\mathrm{mg} / \mathrm{g}$; followed by Ceropegia spiralis $44.4 \pm 3.1 \mathrm{mg} / \mathrm{g}$ and Ceropegia candelabrum $31.4 \pm 0.9 \mathrm{mg} / \mathrm{g}$.

Table 2. Macro and micronutrients of Ceropegia juncea, Ceropegia spiralis and Ceropegia candelabrum in ppm $(1 \mathrm{ppm}=1 \mathrm{mg})$

\begin{tabular}{cccc}
\hline $\begin{array}{c}\text { Macro and } \\
\text { micro nutrients }\end{array}$ & Ceropegia spiralis & Ceropegia juncea & Ceropegia candelabrum \\
\hline Sodium & $502.13 \pm 2.74$ & $622.83 \pm 0.80$ & $434.16 \pm 3.23$ \\
Potassium & $325.86 \pm 0.90$ & $431.8 \pm 1.11$ & $321.13 \pm 0.61$ \\
Zinc & $4.55 \pm 0.04$ & $4.46 \pm 0.40$ & $4.86 \pm 0.05$ \\
Iron & $17.56 \pm 0.25$ & $17.74 \pm 0.25$ & $18.55 \pm 0.11$ \\
Copper & $1.626 \pm 0.11$ & $0.826 \pm 0.06$ & $0.346 \pm 0.01$ \\
Cadmium & $0.028 \pm 0.00$ & $0.032 \pm 0.00$ & $0.033 \pm 0.00$ \\
Nickel & $0.056 \pm 0.00$ & $0.046 \pm 0.00$ & $0.043 \pm 0.00$ \\
Lead & $0.076 \pm 0.00$ & $0.040 \pm 0.00$ & $-0.005 \pm 0.00$ \\
\hline
\end{tabular}

Each experiment carried out with three replicate. Values are represent mean \pm SD.

The mineral elements contained in these plants are very rich. They are good for human consumption. The results of the mineral estimation of the Ceropegia juncea, Ceropegia spiralis and Ceropegia candelabrum are presented in table 2 . Lead was totally absent in Ceropegia candelabrum. The species analyzed in this study contained remarkably high amount of sodium. Ceropegia candelabrum was found to be a rich source of iron (18.55 \pm 0.11$)$ followed by Ceropegia juncea (17.74 \pm 0.25$)$ and Ceropegia spiralis (17.56 \pm 0.25$)$. On analysis, it was also found that these plants were an excellent source of potassium ranging from 431.8 \pm 1.11 (Ceropegia juncea) to $325.86 \pm 0.90$ (Ceropegia spiralis). Zinc content of the Ceropegia species was ranging from $4.86 \pm 0.05$ (Ceropegia candelabrum) to $4.55 \pm 0.04$ (Ceropegia spiralis) and $4.46 \pm 0.40$ (Ceropegia juncea). These species showed to contained less than adequate level of 
cadmium and nickel. The present study showed that the copper content was very less in Ceropegia juncea nearly $1.626 \pm 0.11$ in Ceropegia spiralis. Result analysis shows that all the three species are low in lead, cadmium and nickel constituents.

\section{Discussion and Conclusion}

The present study has clearly established the nutritional value of Ceropegia spiralis, Ceropegia juncea and Ceropegia candelabrum as food for humans (Table $1 \& 2)$. Similar type of work was done by Deshmukh and Rathod, (2013). The tuber of Ceropegia birsute and Ceropegia bulbosa and reported the presence of protein, carbohydrates, $\mathrm{K}, \mathrm{Na}, \mathrm{P}, \mathrm{Ca}, \mathrm{Mg}, \mathrm{Cu}, \mathrm{Fe}$, $\mathrm{Mn}$ and $\mathrm{Zn}$.

Carbohydrates are the important component widely found in plants, Starch is the most common digestible polysaccharide found in foods and therefore a major source of energy in our diets. Sugar, one of the major products of photosynthesis is synthesized in chloroplast (Horemans et al., 1986). Sugar is used as a source of energy by crop plants and its level will decrease with the advancement of age. Among the sampling Ceropegia species maximum sugar content is present in Ceropegia juncea.

Plant food that provides more than $12 \%$ of its caloric value from protein is considered as a good source of protein. The plant Ceropegia spiralis and Ceropegia juncea is a good source of protein. According to Pamela et al. (2005) proteins from plant sources have lower quality but their combination with other sources of protein such as animal protein may result in adequate nutritional value.

Trace minerals are very important in a required amount, but excess or lower amount is harmful to the body. Similarly, mineral nutrition of Ceropegia juncea was reported by Karayil and Vivek (2014). The present study showed mineral estimation of the selected Ceropegia species in table 2. The obtained data reveals that the lead $(\mathrm{Pb})$ constituents of 0.076 \pm 0.00 in Ceropegia spiralis and $0.040 \pm 0.00$ in Ceropegia juncea are present. In the human body lead deficiency results in anemia, while excess lead $(\mathrm{Pb})$ in the body causes brain damage (Stoker, 1976). Lead is a natural constituent of soil, water, vegetation, animal life and air. Significant sources of naturally occurring lead in air include silicate dust from soils and particles from volcanoes. Man is the leading contributor however, as he is manufacturing and using pesticides, combustion of coal, incineration of refuses and gasoline.

According to the Center for Disease Control and Prevention, iron deficiency is the most common nutritional deficiency in the United States. It is also the most common cause of anemia. Iron is very important in the formation of hemoglobin in red blood cells and deficiency of iron leads to anaemia. The iron content of Ceropegia candelabrum (18.55 \pm $0.11)$ followed by Ceropegia juncea $(17.74 \pm 0.25)$ and Ceropegia spiralis $(17.56 \pm 0.25)$. According to Bolt and Bruggenwert (1978) the recommended daily requirement of iron for man is $6-40 \mathrm{mg} / \mathrm{kg}$. Iron is required for hemoglobin formation (Alessandra and Robert, 2005). Certain trace elements such as copper, iron and manganese are to be included in a balanced diet. These micronutrients are sufficient in these three Ceropegia species. Some of them are micronutrient in plants and may not present in the right proportion. This will have adverse effect on both plants and human.

The present study shows that the cadmium content is $0.033 \pm 0.00$ of Ceropegia candelabrum $0.032 \pm 0.00$ in Ceropegia juncea and $0.028 \pm 0.00$ in Ceropegia spiralis. The concentrations of cadmium found in the present study were in accordance with the earlier reports. The normal limits of cadmium content in plants were between $0.2-0.8 \mathrm{mg} / \mathrm{Kg}$ and toxic content of cadmium were defined as 5$30 \mathrm{mg} / \mathrm{Kg}$ (Karayil et al., 2011). Cadmium deficiency causes reduction in growth rate and excess cadmium results in hypertension and nephritis (Stoker, 1976).

Zinc is relatively non-toxic (Prasad, 1981). Zinc is necessary for the growth and multiplication of cells, skin integrity, bone metabolism, functioning of taste and eyesight (Thunus and Lejeune, 1994). Copper in human blood is principally distributed between the erythrocytes and the plasma. Total erythrocyte copper in normal humans is around $0.9-1.0 \mu \mathrm{g} / \mathrm{ml}$ of packed red cells (Mason, 1979). The deficiency of copper has been associated with cardiac abnormalities in human and animal cause's anaemia and neutropenia (Mills et al., 1976). Several micronutrients such as $\mathrm{Cr}, \mathrm{Mn}, \mathrm{Fe}, \mathrm{Cu}, \mathrm{Zn}$ etc in our diet in traces plays an important role in the metabolic processes. Their excess or deficiency may disturb normal biochemical functions of the body.

The present study shows that Ceropegia plants plays an important roles in the maintenance of health and curing of diseases. Therefore, an attempt has been made to show that these plants have the potential to be used as Nutraceuticals i.e. as food and medicine.

\section{References}

1. Ahmedulla M and Nayar MP. Endemic plants of the Indian region Peninsular India, Botanical Survey of India. 1986, vol.1, Kolkatta.

2. Alessandra $G$ and Robert HC. The crucial role of metal ions in neuro degeneration: the basis for a promising therapeutic strategy, British Journal of Pharmacology. 2005,146 (8): 1041 - 1059. 
3. Ansari M Y. Asclepiadaceae: Genus CeropegiaFascicles, In Flora of India, Botanical survey of India, Calcutta 1984,16: 1-34.

4. Archana S, Jatawa S, Paul R and Wari A. Indian Medicinal plants: A rich source of natural immunemodulator, International Journal of Pharmacology. 2011, 9: 198-205.

5. Bapat V A, Yadav S R and Dixit G B. Rescue of endangered plants through biotechnological applications, National academy Science letters. 2008,31: 201-210.

6. Bolt G H and Bruggenwert W G. Solid Chemistry, basic elements. Elsevier Scientific Publishing Co., New York, 1978, pp. 145.

7. Cambell M M, Bruner AM, Jones HM and Strauss SH. Forestry's fertilecresent: The application of biotechnology to forest tress. Plant Biotechnology Journal, 2003, 1: 141-154.

8. Dave A, Bilochi G and Purohit SD. Scalling-up production and field performance of micropropagated medicinal herb "Safed Musli" (Chlorophytum borivilianam), In vitro Cellular and Developmental Biology Plant. 2003,39: 419-424.

9. Deshmukh SR and Rathod V. Nutritional composition of wild edible Ceropegia tubers. Advances in Applied Science Research. 2013,4(1): 178-181.

10. Erdogrul OT. Antibacterial activities of some plant extracts used in folk medicine. Pharmacology Biology. 2002, 40 (4): 269-273.

11. Goyal D and Bhadauria S. In vitro propagation of Ceropegia bulbosa using nodal segments. Indian journal of biotechnology. 2006, 5; 565-567.

12. Horemans S, De Koninck K, Neuray J, Hermans R and Assak J. Production of plant growth substanus by Azospirillum and other Rhizasphere baeteria. Symbiosis. 1986, 2: 341-346.

13. Karayil S, Mallikarjun Rao Y, Veeraih K, Sambasiva Rao K R S. Somalata-A Pioneer Herb in the entire Plant Kingdom-Ethno pharmacological Perspective Through Vedic Literature. International Journal of Research in Pharmaceutical and Biomedical Sciences, 2011, 2 (2): 977-981.

14. Karayil S, Vivek B. Heavy Metal Analysis from Traditionally used Herb Ceropegia juncea. IOSR Journal of Pharmacy. (e) - ISSN 2014, 2250-3013.

15. Krishnaraju A V, Rao T V N and Sundararaju D. Assessment of bioactivity of Indian medicinal plants using Brine shrimp (Artemia salina) lethality assay.
International Journal of Applied Science and Engineering, 2005, 2: $\quad 125-134$

16. Mahesh B and Satish S. Antimicrobial activity of some important medicinal plants against plant and human pathogens. World Journal of Agricultural Sciences, 2008, 4: 839-843.

17. Mason K E. A Conspectus of Research on Copper Metabolism and Requirement of Man Nutri. Journal of Nutrition, 1979,109.

18. Mills C F, Dalgarno A C and Weoham G. Biochemical and pathological changes in tissues of Friesian cattle during the experimental in duction of copper deficiency. British Journal of Nutrition, 1976,35: 309-311.

19. Murch S J, Choffe K L, Victor J M R, Slimmon T Y, Raj $K$ and Saxena P K. Thiazuron-induced plant regeneration from hypocotyls cultures of St. John's wort (Hypericum perforatum L.cv. Anthos). Plant Cell Reports, 2000a, 19: 576-581.

20. Nayar M P Sastry A R K. Red Data Book of Indian Plants Vol. 1. Botanical Survey of India, Calcutta 1987.

21. Pamela C C, Richard A H, Denise R F. Lippincotts illustrated Reviews Biochemistry $3^{\text {rd }}$ ed., Lippincott Williams and WiLkins, Philadelphia 2005, Pp.335388.

22. Prasad A S. Zinc deficiency and effects of zinc supplementation on sickle cell anemia subjects. Progress in Clinical and Biological Research Journal, 1981, 55: 99-122.

23. Sidhu Y. In vitro micropropagation of medicinal plants by tissue culture. The Plymouth Student Scientist 2010,4 (1): 432-449.

24. Stoker S H. Environmental Chemistry; air and water pollution. $2^{\text {nd }} \mathrm{ed}$., Wiley Interscience Publishers, U. S. A. 1976, 2-29.

25. Thunus L Lejeune R. Hand book on metals in clinical and analytical chemistry, New York: Dekker 1994, 333 667.

26. Uniyal SK, Singh KN, Jamwal P, Lal, B. Traditional use of medicinal plants among the tribal communities of Chhota Bhangal, Western Himalayan. Journal of Ethnobiology and Ethnomedicine 2006, 2: 1-14.

\section{Cite this article as:}

Binish T. and Pushpa R. Pharmaceutical and nutraceutics on three endemic species of Ceropegia. Annals of Plant Sciences 7.5 (2018) pp. 2221-2225.

http://dx.doi.org/10.21746/aps.2018.7.5.3

Source of support: U.G.C., New Delhi, India.

Conflict of interest: Nil 